\title{
Corporate Social Responsibility and Multinational Enterprise Identity: Insights from a Mining Company's attempt to localize in Ghana
}

\author{
Swetketu Patnaik ${ }^{\mathrm{a}}$, Yama Temouri ${ }^{\mathrm{bc}}$, James Tuffour ${ }^{\mathrm{a}}$ and Shlomo Tarba ${ }^{\mathrm{d}}$, Sanjay Kumar Singh \\ ${ }^{a}$ Lord Ashcroft International Business School, Anglia Ruskin University CB1 1PT, United Kingdom \\ ${ }^{\mathrm{b}}$ Aston Business School, Aston University, Birmingham B4 7ET, United Kingdom \\ c University of Wollongong in Dubai, Faculty of Business, United Arab Emirates. \\ ${ }^{\mathrm{d}}$ Birmingham Business School, Birmingham University, Birmingham B15 2TT, United Kingdom \\ e Abu Dhabi University, College of Business Administration, United Arab Emirates
}

\begin{abstract}
This paper investigates how a United States gold mining multinational enterprise (MNE) — one of the world's largest—operates its subsidiaries in various parts of the world by creating a unique "glocal identity". The US parent company has experienced several significant challenges across its network of subsidiaries. These challenges were mostly linked to the enforcement of the MNE's identity and culture in its host environment. We contribute by describing, in detail, the attempts made by this company to localize its Corporate Social Responsibility practices in Ghana as it sought to gain legitimacy and create an identity that would overcome the issues relating to the liability of foreignness. Our data come from a combination of sources, including questionnaires and detailed semi-structured interviews conducted with the key management employees of the mining company, members and opinion leaders of the company's host communities, and secondary sources. Our main finding is that the construction of a 'host friendly' identity was centred around the mining company's involvement with the Newmont Ahafo Development Foundation.
\end{abstract}




\section{Introduction}

The existing theory and research in international business (IB) provides a negative view of foreignness, distance, and differences in, for example, national, cultural, organizational, and institutional aspects, with an emphasis on liabilities and adverse outcomes thereof (Stahl, Tung, Kostova \& Zellmer-Bruhn, 2016). Furthermore, while the extant research is certainly valuable, its focus on primarily negative processes and outcomes has hindered the understanding of the dynamics, processes, and conditions that enable organizations to benefit from diversity in a wide range of IB contexts (Stahl, Tung, Kostova \& Zellmer-Bruhn, 2016). Drawing on institutional theory, Kostova \& Roth (2002) identified two factors influencing the adoption of a practicenamely: a) the institutional profile of the host country; and b) the relational context within the MNE. Thus, MNEs operate in complex environments characterised by multiple, diverse, and possibly conflicting institutional and cultural forces (Pereira and Malik, 2015), which could also affect a company's adoption of corporate social responsibility (CSR) practices. Based on the study conducted on 710 US MNEs with global ties to over 100 countries between 2007 and 2011, Marano \& Kostova (2016) identified a set of factors that make certain pressures more salient than others, including a company's economic dependence on a particular country, any heterogeneity of the institutional forces within the company's transnational field, exposure to leading countries with more stringent CSR templates, and the intensity and commitment to particular economic linkages 
(i.e., foreign direct investment versus international trade). Bachman and Pereira (2014) come up with the term 'corporate human rights responsibility' (CHRR), wherein they develop and build upon this emerging concept the context of emerging market multinationality (EMM), by proposing that MNEs are more proactive in taking on board CHRR within their corporate governance and CSR agendas.

The extractive industries, which include the oil, gas and mining sectors, are an important part of the economies of many developing countries. In the specific context of low and mediumlow income countries, such as those in Western-Africa, the extractive industries account for a staggering 75 to $80 \%$ of the total exports and 45 to $50 \%$ of total government revenues (Halland et al., 2015; IMF, 2012). It is this focus on extractive industries that has made countries in Western Africa witness significant increases in foreign direct investment (FDI), particularly in the mining sector, during the 2000-2012 period (UNCTAD, 2015).

Scholars attribute the growth in FDI in sub-Saharan African countries to the incentive packages, such as tax breaks and low royalties, offered by the host country governments to MNEs (see, for instance, Hilson, 2012). At the same time, most of these countries are characterized by weak and corrupt governance systems, widespread poverty, and the lack of any resemblance of labour unions; this, in turn, enables MNEs to dictate the terms and scopes of their investments 
(Hilson \& Maconachie, 2009; Hilson, 2012). As a consequence, one of the fundamental challenges faced by these resource-rich countries is how to translate the benefits provided by their natural resources into long term sustainable socio-economic development for the regions in which the resources are located (Garvin et al., 2009).

MNEs that are keen to invest in these locations find it challenging to navigate through the complex local socio cultural, economic, and institutional settings. In this context, creating and maintaining important relationships with local stakeholders, including community members, becomes paramount to successfully operate in extractive resource-rich countries. Therefore, the exploration of ways to mitigate stakeholder related risks ranks very high on the agenda of MNEs involved in the extractive industries (Davis \& Frank, 2014).

Despite the increasing importance attached to CSR activities in host countries, few studies have highlighted the challenges faced by MNEs in dealing with CSR issues that are of importance to their respective host countries (Logsdon \& Wood, 2005). Equally, there is a dearth of research providing insights into how MNEs use their CSR activities to interact with various stakeholders in their host countries with the aim of gaining legitimacy (Husted \& Allen, 2006; Beddewela \& Fairbass, 2016). 
The importance of this special issue topic lies in the limited understanding of how MNEs develop and adjust their identities when internationalising, especially in emerging market countries. An MNE’s identity in its home country setting has a strong influence on its strategy, operation, and behaviour in the marketplace. However, due to the many different factors outlined by social identity theory, this identity may be of little value to the MNE when it tries to establish its operations in foreign markets (Ashforth \& Mael, 1989). The differing perspectives that may be held by stakeholders in host countries create a significant social identity challenge for MNEs in their quests to understand and manage their additional liabilities of foreignness.

Thus, through this paper, we contribute to and aim at filling the gap identified above in the literature on the social identities of MNEs by providing case study evidence for how a US based mining company localized its CSR policies in Ghana to maintain its corporate identity. We highlight detailed issues in terms of the challenges faced by the MNE in implementing its CSR activities and managing its various stakeholders in Ghana. We find that the localization of its CSR policies was central to the MNE's strategy and behaviour aimed at developing a "glocal identity" (Robertson, 1994) in the host country to gain legitimacy and overcome the issues relating to the liability of foreignness (Zaheer, 1995). 
The remainder of the paper is structured as follows. In section 2, we begin by reviewing the literature on the internationalization of MNEs and explore the challenges posed to them by the liability of foreignness. In section 3, we review the literature on CSR, particularly focussing on the body of work that calls for organizations to take a strategic view of programmes aimed at gaining reputation and identity. Section 4 describes the research design and how our data were collected and analysed. This is followed, in section 5, by a discussion of our findings in relation to the localization of CSR policies aimed at maintaining corporate identity. We conclude, in section 6, with a discussion of the implications of our findings for future research on CSR and identity.

\section{Internationalisation and the liability of foreignness}

We explain the success of the US mining MNE's subsidiary in Ghana by drawing on the concept of the liability of foreignness coupled with insights from institutional theory. The liability of foreignness concept, which has its origins in the international business literature (Hymer, 1976; Kindleberger, 1969; Zaheer, 1995), states that MNEs face significant upfront costs when setting up subsidiaries in foreign markets. These sunk costs arise from the differences that exist between the MNEs' home countries and the host ones in which they decide to set up their subsidiaries.

For example, companies may be unfamiliar with the business environments found in the host countries, which involve cultural, institutional, political, and economic factors. Some of these 
sunk costs, such as those connected to learning about setting up a business and paying corporate taxes, can be overcome relatively easily. However, there are other subtle and complex challenges, such as dealing with corruption or the network based relationships that can only be built over long periods of time (Gaur et al., 2007). This unfamiliarity means that MNEs need to invest significant time, effort, and resources in learning about the various dimensions of their host countries. This is essential if MNEs are to reduce their disadvantages and compete successfully vis-à-vis the local companies that are already operating in the host countries. A recent study by Munjal \& Pereira (2015) showed that the local embeddedness of mergers and acquisitions is strengthened by the acquiring MNEs’ persistence in learning from local emerging host country contexts.

In turn, the ability to overcome the challenges brought by the liability of foreignness means that MNEs need to possess significant and unique company-specific advantages that can be exploited in foreign markets. Only then can foreign expansion be made worthwhile by the company-specific advantages outweighing the sunk costs incurred during the host country learning phase. These company-specific advantages can come in the form of the superior resources (e.g., technology) and other managerial or organizational advantages that are transferred from the parent headquarters to the subsidiary in the host country. The superior performance of foreign investors over domestic companies has become a stylised fact in the applied and policy-oriented literature concerned with FDI flows or with the impacts of inward investment. In this vein, in their 
comprehensive review of the existing research on headquarters-subsidiary relationships, Kostova, Marano \& Tallman (2016) highlighted the need for the further exploration of novel trends and approaches in elucidating the links of this topic with the broader field of international management research and practice. For instance, Hoenen \& Kostova (2015) identified key unresolved issues in headquarters-subsidiary relationships; these include closing the gap between headquarters' expectations and subsidiary performance, managing nested hierarchical relationships across multiple organizational layers, and aligning these relationships across diverse subunits embedded in different social contexts. Pereira, Munjal and Nandakumar (2016) in their study provide a conceptual framework and typology to measure headquarters and subsidiary dependency on capabilities and resources. Using an in-depth longitudinal case study approach, their paper highlights a novel phenomenon called "reverse dependency," which indicates that a headquarters dependency on its subsidiary is rising. Furthermore, departing from classical agency theory, Kostova, Nell \& Hoenen (2016) recently proposed an agency model for headquarters-subsidiary relationships in MNEs with headquarters as the principal and the subsidiary as the agent. They maintained that, in the organizational setting, one cannot assume the absolute self-interest and perfect rationality of agents (subsidiaries), but should allow them to vary through the set of internal organizational and external social conditions in which the headquarters-subsidiary agency dyad is embedded. Another interesting aspect refers to the examination of the fulfilment of complex roles 
played by managers when they develop a dual organizational identification towards both entities (the MNE and the subsidiary). Vora, Kostova \& Roth (2007) indicated that a high identification with both entities is associated with a high role fulfilment and that any similarity in organizational identities directly affects role conflict.

However, in host country settings that are culturally and institutionally very different from those found in the home country, a MNE may try to minimise its foreignness by mimicking the behaviours of those local companies that are seen as better performing due to their familiarity with the country, industry, and consumers. This view emanates from institutional theory, which argues that companies behave similarly by following a set of written or tacit rules and strategies in order to signal their commitment and legitimacy to the host country and thereby be accepted, thus increasing their chances of survival (DiMaggio \& Powell, 1983). This enables MNEs to adapt to different institutional environments by limiting their risk and reducing their transaction costs. In brief, the goal of MNEs lies in the virtue of fitting in and playing by the rules of the game in a manner that is similar to that of local companies. This is called "isomorphism" by organization theorists and "strategic herding" in the management literature. Both terms represent those changes that make companies and other organisations more similar to each other. 
Therefore, subsidiaries around the world are faced with the dual pressure of conforming both to their parent MNEs' global organisation and standards to achieve internal legitimacy, and to their host country environments to reduce their liability of foreignness. This is particularly important in the case of emerging market countries (Nachum, 2003), in which the liability of foreignness can be significant and thus create enormous challenges. In general, these challenges emanate from the MNEs' efforts to impose their corporate identities in their host countries; this, in the face of the managers' bounded rationality and/or of the reliability of the host countries, provokes local stakeholder hostility

\section{CSR as a mechanism to localise social identity}

CSR is considered to be a Western concept that gained popularity in the 1980s (see Blowfield \& Frynas, 2005), and that was subsequently spearheaded in developing countries, particularly by companies active in the extractive industry (Hilson, 2012). Despite a burgeoning body of literature on CSR, there is no agreement on a single definition of the concept (Torugsa et al, 2012). Broadly speaking, CSR pertains to those formal and informal ways in which enterprises contribute to improve governance, social, ethical, labour, and environmental conditions in the developing countries in which they operate, while remaining sensitive to the prevailing religious, historical, and cultural contexts (Visser et al., 2007). Simply put, the common thread that links different 
conceptualisations of CSR is the relationship between an enterprise and the society in which it is embedded (Matten \& Moon, 2008). In this context, one notes a certain degree of congruence amongst some scholars, who posit that companies—and MNEs in particular—can accrue benefits if they proactively embrace the environmental and community development concerns of their host countries (Dunphy, 2003; Jenkins, 2009). However, it is widely acknowledged that, in the specific context of developing countries, there is a wide gap between what CSR means and stands for and how it is implemented by different corporate entities (Hilson, 2012). The extant literature on CSR implementation points at two broad approaches that companies—and MNEs in particular—adopt in host country environments. Companies that operate in host countries that are geographically and institutionally closer to the home country environment pursue either a global strategy (Muller, 2006) or a strategy akin to the one they implement in their home countries (Munjal \& Tripathy, 2015). However, in host countries that are both geographically and institutionally remote, MNEs tend to either improvise and localize their CSR strategies (Muller, 2006) or simply use CSR as rhetoric (Hilson, 2006). Hence, Banerjee’s (2001) assertion that, in contrast to developed countries, where CSR complements a set of robust check and balance mechanisms, in developing ones, which are often characterized by weak enforcement of legislation and rampant corruption, companies find themselves in situations that allow or require them to self-regulate and, in the process, act as the 'de facto government' (see Blowfield \& Frynas, 2005). Therefore, some scholars asserted that CSR 
has inevitably become critical for corporate reputation (Garberg \& Fombrun, 2006; Hillenbrand \& Money, 2007) and has hence come to represent a critical aspect of corporate identity (Balmer et al, 2007; Arendt \& Brettel, 2010). A CSR based corporate identity and reputation-particularly in the context of the extractive industry and, most specifically, the mining sector-is considered critical to generate good community relations. It has been suggested that working closely with local communities could help companies to positively contribute to the wider socio-economic development of the areas in which they operate and help mitigate the issues relating to the liability of foreignness (Moeller et al, 2013).

\section{Research setting and methodology}

In Ghana and other Sub-Saharan Africa countries, mining dates as far back as the pre-colonial era (Garvin et al, 2009; Government of Ghana, 1980). Ghana is naturally endowed with mineral resources like gold, manganese, diamond, bauxite, aluminium, and many others. Its extractive industry is the leading source of foreign exchange and drives other economic activities by attracting foreign direct investment and boosting domestic revenue generation and job creation (Akabzaa, 2009; Forstater et al., 2010). The extractive industry in Ghana has been mostly dominated by gold mining and the country ranks amongst the top 10 global producers of gold (US Geological Survey, 2016). Gold production in Ghana accounts for between 80 and $90 \%$ of the extractive sector's output 
(Appiah-Adu \& Bawumia, 2016; US Geological Survey, 2016). In the financial year 2013-14, Ghana's export income from mines stood at about US $\$ 4.9$ billion, representing $44 \%$ of the country's total merchandise export in 2016 (Bank of Ghana, 2016). According to the Ghana Chamber of Mines (GCM) (2014); the industry's tax revenue for 2013-14 was 1.24 billion Ghanaian Cedis (US\$540 million), representing 14.3\% and 18.7\% of total domestic and direct tax revenues respectively (ibid). Global industry players like the Newmont Corporation, Goldfields, and AngloGold Ashanti operate several mines in Ghana. Apart from the MNEs, there are many other small and medium-scale enterprises licenced by the Government of Ghana through the Minerals Commission (Ministry of Lands and Natural Resources, 2004).

The Newmont Corporation is a US based mining company that has an operational presence in five countries worldwide: the United States of America, Australia, Ghana, Peru, Mexico, and New Zealand (Newmont, 2014a). Today, with about 29,000 employees and contractors, Newmont continues to be one of the key players in the mining industry (Newmont, 2014b). The company considers its operation in Ghana to be stable and not presenting any social or political risks, which is not the case with its operations in Indonesia and Peru (Annual Report, 2014-15). In this context, it is critical to highlight that the Newmont Corporation sold off its operations in Indonesia in early 2016 due to the unmanageably high social and political risks (Welker, 2009). Its operations in Peru have also attracted the attention of various groups-including widespread protests from the local 
community—due to environmental issues and the company's highhanded actions in resolving local problems1.

The Newmont Corporation’s subsidiary in Ghana is called Newmont Ghana Gold Limited (henceforth, NGGL). NGGL commenced its commercial exploration of gold in Ghana at the Ahafo Mines, in the Brong-Ahafo region, in 2006. In December 2003, Ghana's Parliament had unanimously ratified an investment agreement between the Newmont Corporation and the Government of Ghana. The investment agreement established the fiscal and legal regime underpinning NGGL's operations. The fiscal regime included the royalties and taxes the company would pay to the State's exchequer during the life of the project in Ghana.2 NGGL, together with its contractors, employs approximately 6,000 people in two mines and produces about 550,000 ounces of gold per annum (Newmont, 2017). The Ahafo mines encompass two administrative districts and cover ten major communities. A living standard survey conducted by the Ghana

\footnotetext{
${ }^{1}$ On May 3, 2017, the Supreme Court of Peru ruled in favor of local potato farmers who were protesting against Newmont's use of their land. The company's plans to expand its presence in Peru by building the Conga mine have been put on hold following protests from local community

${ }^{2}$ Under the Investment agreement, the Newmont Corp. would pay corporate income tax not to exceed 32.5\% and fixed gross royalties of $3.0 \%$ on gold production (3.6\% for any production from forest reserve areas). The Government of Ghana was also entitled to receive $10 \%$ of the project's net cash flow, after Newmont had recouped its investment, and $20 \%$ of the production. The investment agreement also contained commitments with respect to job training for local Ghanaians, community development, the purchase of local goods and services, and environmental protection (Source: www.sec.gov/archives; accessed on 25.12.2016)
} 
Statistical Service in 2008 found that the two districts are rural and lack many basic social amenities such as education and health infrastructure, portable pipe-borne water, and road networks. Thus, NGGL is envisaged to play a critical role in the development of the region.

We collected data between December 2014 and June 2015. We used several data sourcesnamely: (a) our initial data was generated from a survey questionnaire; (b) the qualitative data was generated from semi-structured interviews; and (c) our archival data was sourced from corporate documents, press releases, annual reports, and other investor presentations of the company's CSR initiatives and activities.

In the first phase, we collected data through by administering a questionnaire to 103 respondents that had been selected by means of a random sampling technique. This technique ensures that all members of a target population are provided an equal opportunity to be selected for a study (Cooper \& Schindler, 2006). The population surveyed consisted of both NGGL employees and members of the communities in which the mines operated. The research participants were drawn from both the MNE's officials and the local communities to ensure that the data collected for the study were more representative. Hence, our findings do not stem from the responses provided only by a single section of the population. Eighty-two questionnaires were retrieved from the sampled population, representing $79.6 \%$ of those originally distributed. In a similar study 
conducted by Welford \& Dixon (2010), the retrieval rate was 37\%. The high rate of response for this study reflects the fair representation of the sampled population (Gao, 2007). The summary of the sample population is provided in table 1.

(Please insert table 1 here)

The questionnaire was carefully designed in three main parts: a) personal data; b) the benefits and factors motivating CSR; and c) the level of stakeholder participation in the formulation and implementation of the CSR strategy. The first part provided information about the gender of the participants, the number of years they had worked/encountered the company under study, and their awareness of the company's CSR policies. Also, this part of the questionnaire suggested seven key CSR motivating factors, and asked the participants to assign them a value ranging from one to seven in increasing order of importance. Furthermore, the participants were also asked to disclose other factors about how they attributed to NGGL's CSR activities. The responses from the survey respondents pertaining to NGGL's motivation for CSR are in Figure 1. 
(Please insert Figure 1 over here)

The responses from the questionnaire, particularly those regarding the perceptions of the respondents pertaining to the company's motivation to engage in CSR activities, encouraged us to undertake a more in-depth study. In the second phase, we conducted semi-structured interviews with 14 key individuals to develop a fine-grained understanding of how NGGL approaches and implements its CSR strategy in the region. The interviewee sample consisted of some management employees of NGGL, and members and opinion leaders of the company's host communities. The responses obtained from the questionnaires and interviews provided us with insights into: (a) the motivating factors that drive the CSR initiatives of NGGL in the region; and (b) the approach the company adopts to implement its CSR initiatives, and in the process, create and localize its 'hostfriendly’ identity. We used archival sources to complement the data and insights we generated from the survey and interviews. The list of the interviewees is provided in table 2. 
(Please insert Table 2 here)

\section{Findings}

The review of the literature on the extractive industry and CSR suggests that, although CSR ranks high on the agenda of mining enterprises, there is lack of agreement on whether these enterprises adequately implement their CSR strategies in their host country settings and, if they do, how they actually implement them in practice (Hilson, 2012; Banerjee, 2001; Blowfield \& Frynas, 2005).

By contrast, through NGGL, the Newmont Corporation has facilitated the creation of a successful structure that is at the core of its CSR implementation in partnership with the local community. In this context, the Newmont Ahafo Development Foundation (NADeF) has become an effective vehicle to facilitate the localization of NGGL's CSR initiatives in the region. By building on our understanding of this special structure underpinning the partnership between NGGL and other local stakeholders, we discerned the overarching motivation of the CSR initiatives pursued by the subsidiary. In the final part of this section, we present our findings on the localization of NGGL's CSR initiatives, which led to its legitimization within the local community.

\subsection{Localization of CSR and community engagement structure}

The first thing we noted about the localization of NGGL's CSR strategy is that it rests on three major institutions—namely, the Ahafo Social Responsibility Forum (ASRF); the Newmont Ahafo 
Development Foundation (NADeF), and the Sustainable Development Committees (SDCs) which are community-based and dominated by indigenous people.

In 2005, almost a year before the mining operations at Ahafo mines commenced, Wayne W Murdy, the Chief Executive Officer (CEO) of the Newmont Mining Corporation visited Ghana and announced that NGGL would contribute one US dollar per every ounce of gold extracted from the Ahafo mine enclave (NADeF, 2009). He also announced that the company would allocate $1 \%$ of the net annual pre-tax profits to the sustainable development of the local communities (ibid)3. The gesture from the CEO of Newmont Corporation was, we would argue, about assuaging the local communities about his company's commitments to the development of the local region.

Subsequently, the ASRF was established in 2006 with 53 members representing a diverse set of stakeholders including: traditional leaders, local councils, advocacy groups, nongovernmental organizations, and the management of NGGL (Ayee, 2011; Mares, 2012). The ASRF, which is the highest decision making body for the NADeF, represents the interests of the local communities. This forum, which came into being on the initiative of the members of the local community, engaged with NGGL to explore ways to effectively execute the commitments

\footnotetext{
${ }^{3}$ Ghana became a centre for mining with the arrival of the Portuguese and Arab traders. Between 1957, when Ghana attained independence from the United Kingdom and 1972, when the sector was nationalised and taken over by the State, foreign MNEs dominated the landscape of Ghana's mining sector. In mid-1980s major State owned mining companies were privatised against the backdrop of the IMF Structural Adjustment programme.
} 
undertaken by the CEO (NADeF, 2009). After consultations lasting over two years, the Ahafo Social Responsibility Agreement (ASRA) was signed in 2008 between NGGL and the people of the Ahafo Mine local communities (Owusu-Ansah, 2015). The ASRA is underpinned by three main agreements: (a) a relationship agreement that provides the modalities governing the relationship between NGGL and the communities affected by the mining activities; (b) an employment agreement that spells out the modalities relating to local content; and (c) the NADeF agreement, which focusses on the funding and implementation of various sustainability development projects in the communities.

The NADeF was incorporated in 2008 as a trust. Its nine-member Board of Trustees oversees the implementation of the three agreements. The respondents referred to the NADeF as a "special structure” wherein the communities in the mining region are "fully represented". The key motivation for the formation of the NADeF was highlighted by one of its trustees. She asserted that:

“in 2008, an agreement was signed between NGGL and some local stakeholders. The leading stakeholders were the local communities, represented by ASRF and certain Civil Society Groups. We were mindful of the effects of mining in certain local communities in Ghana and wanted to take proactive measures in order not to experience the same in our 
communities. We brought the NADeF to distribute fairly mining proceeds for our community development.” (Trustee, NADeF)

As per the CEO’s 2005 commitment, between 2008 and 2015, NGGL contributed about 50.5 million Ghana Cedis to the NADeF towards various projects for the development of the local communities (NADeF, 2015). Over the same period of time, the NADeF board of Trustees disbursed about 25.41 million Ghana Cedis of the money received and invested the remaining 25.09 million in an endowment fund to be used after the closure of the mines. Below, we provide the figures regarding the various developmental programmes sponsored by the NADeF since 2008 .

(Insert Figure 2 over here)

The NADeF structure is made up of ten sustainable development committees (SDCs), which are community-based teams, each of which was established and represents one of the ten Ahafo communities affected by NGGL's mining activities. Thus, the SDCs serve as a link between the communities and the NADeF. The main role of these committees is to identify and appraise projects/initiatives within their respective communities and submit them to the NADeF for sponsorship. The committees undertake these responsibilities by engaging all the indigenous stakeholders. The engagement process includes periodic meetings with the residents. The 
relationships maintained among the three institutions, which facilitate the implementation of NGGL's commitment to contribute proceeds from its operations towards community development, is depicted in figure 3 .

(Insert Figure 3 here)

The distinctiveness of the NADeF stems from its adequate representation of its constituent local communities, which provides representatives of the local communities with the opportunity to be involved in the evaluation of the developmental proposals and the implementation and monitoring of the approved developmental projects. In this context, one of the opinion leaders asserted:

"We have large communities, as many as ten, and under two different local government structures. Others [mining developments] have fewer communities and different culture, beliefs and norms. To us, a consultative group like NADeF reflects our tradition. Our culture supports working with opinion leaders to facilitate harmony.” (Interviewee 9).

The above quotation highlights two critical issues. First, it is recognised that a collective functioning or consultative approach is central to achieving the long-term development of the 
region and, in that context, the NADeF provides a space in which the ten local communities can suggest potential developmental programmes. The consultative approach entails regular periodic interaction between NGGL, which effectively sponsors the developmental programmes, and the other representatives of the NADeF and ASRF, who submit various initiatives based on the proposals received from the SDCs. In that context, the NADeF provides a platform in which the interaction between NGGL and the members of the local communities can take place. The second issue relates to how the local communities view the presence of the MNE in their midst. It is widely acknowledged that the CSR initiatives undertaken by MNEs in the extractive industry in countries with weaker institutions fail to deliver adequate long-term results (Hilson, 2012; Campbell 2012). Thus, seen through the lens of CSR performance, we would argue that the existence of a structure such as the NADeF ensures that the benefits produced by mining in the region are directly reinvested back in the local communities. Put simply, participatory decision-making, wherein the voices of the local community are not lost in the corridors of NGGL, underpins the effective longterm development of the mining regions.

The interaction between the three institutions of the NADeF, SDCs, and ASRF ensures that matters relating to community development remain at the forefront so far as the financing of developmental initiatives is concerned. In this regard, one of the Opinion Leaders provided us with insights into the functioning relationship between the NADeF and the SDCs: 
"We liaise with the NADeF in identifying community projects. The SDC then writes proposals, justifying the benefits of the identified project to the community concern. We also monitor the progress of approved work and report same to the NADeF Secretariat."

The above assertion highlights the functioning of a bottom-up approach system, not only when a proposal is drafted, but also when a project is being implemented. This approach ensures that NGGL does not impose development projects on its local communities. Instead, the communities assess their own needs, seek approval from the NADeF, and monitor the progress of work. Simply put, even though NGGL contributes financially, it does not exclusively decide which projects are justifiable and which are not.

Most respondents acknowledged the positive contributions made by the NADeF, which also has a representative from NGGL as one of its trustees. The response given by one of the Traditional Rulers aptly captures this point:

"They [the NADeF] are doing a very good job. We [the communities] have been provided with schools, a health post and a community centre ... most of our children are awarded scholarships to senior high schools. This was rare before the mining operations commenced"

In Ghana, traditional rulers are viewed as the custodians of local culture (see, for instance, Augustine. 2016; Asante et al., 2017). The above quotation from one traditional ruler suggests that 
the NADeF is considered as the central entity that has constructively engaged with NGGL in delivering social and infrastructure development. Interestingly, most of the respondents identified the developmental initiatives funded by NGGL through the NADeF. This is important because, in the past, the mining communities of the region were considered among the most underdeveloped in Ghana, (Ghana Statistical Services, 2008) and were solely depended on the government for the provision of developmental projects that were not always forthcoming.

Interestingly, although our respondents acknowledged NGGL's financial contributions to the NADeF, they did not hesitate to suggest that the company could do more than it had promised. The views of another Traditional Ruler summed up this view:

"They [the NADeF] are working very hard. I think they can do better if we increase the funding received from the sponsor. I have the feeling that NGGL can give better than 1\% of their profit. There are many other social amenities our communities would be provided with if funds were available."

Although the empirical evidence suggests that, in many developing countries, MNEs take advantage of weak regulations in the areas of community development and environmental responsibility (Cuervo-Cazurra \& Genc, 2008), the comments made by the Traditional Ruler suggest that the local communities are conscious of NGGL's operations and expect a fairer share of the profit. 
Arguably, Newmont's strategy of involving its stakeholders (specifically, local communities) in the formulation and implementation of CSR programmes is intended to mitigate any possible local discontent or social risk, particularly against the backdrop of the opposition that the company encountered in Peru and Indonesia (see, for example, Stern, 2016; BBC, 2011; Perlez, 2005; Johnston, 2006). Newmont introduced and embraced this concept of corporate-community participation in Ghana to win the support of its host communities. This provides an illustration of NGGL's attempt to create a 'host-friendly' identity in Ghana to enhance its corporate reputation. We argue that the creation of this 'host-friendly' identity is critical for the company, particularly against the backdrop of the loss of reputation it suffered due to its mishandling of social and environmental issues in Peru and Indonesia.

Considering that NGGL also uses the NADeF as a mechanism to undertake and localize its CSR initiatives, it is critical that local communities observe and acknowledge the relationship. A critical examination of the relationship that exists between NGGL and the NADeF helps us to discern the motivation for NGGL's CSR activities in the region.

\subsection{Motivation of NGGL's CSR}

It is increasingly argued that companies engage in CSR activities motivated by the desire to enhance corporate reputation (Garberg \& Fombrun, 2006; Hillenbrand \& Money, 2007); hence, such activities represent a critical aspect of corporate identity (Balmer et al, 2007; Arendt \& Brettel, 
2010). Our findings from the survey highlighted that most of the respondents considered NGGL's attempts to project corporate reputation as the key motivation for its undertaking of CSR activities. The senior managers we interviewed acknowledged that the CSR activities undertaken by the company are part of their efforts to create a favourable image among its stakeholders4. In this context, an official informed us that:

"Our CSR activities are voluntary. As a company, we have fulfilled all the legal requirements to enable us to operate this mining field. No law in Ghana enjoins us to undertake developmental projects in our communities. However, we are mindful of our operational impact on our communities and strive to live in harmony with them. With this in consideration, we have voluntarily adopted several international best practices to protect the environment, and contribute to their social development."

We can discern two critical issues from the above quotation. First, it is an illustration of how MNEs view CSR in general. CSR is considered as a 'voluntary obligation' to be fulfilled by the company. Without any legal or institutional oversight on their respective CSR activities, the MNEs are under no obligation to do any more than that they perceive as necessary. The voluntary

\footnotetext{
${ }^{4}$ Before commencement of operation in Ahafo, some Civil Society Groups had campaigned against Newmont's entry into the Ghanaian market because of their previous record of environmental pollution in other developing countries.
} 
conception of CSR, in essence, captures the ambiguities associated with the concept and how it is implemented by MNEs (Blowfield \& Frynas, 2005; Torugsa et al, 2012). At the same time, the respondent also acknowledged that the company has a social obligation to the local communities and, hence, a motivation for CSR. However, it is important to emphasise here that, although the announcement made by the CEO in regard to contributing a specific amount had been voluntary, by coming together and forming the ASRF, the local communities ensured that they would be able to facilitate that commitment ${ }^{5}$. So, irrespective of the manager's opinion about the company's contribution being voluntary, in effect, it is not; it is bound by its agreement with the ASRF to contribute said amount.

The second issue we discern from the quotation pertains to the essence of the maintenance of a harmonious relationship with the local communities. Other respondents also highlighted the link between CSR and reducing the necessity to avoid conflicts with the local communities. One of the respondents from NGGL aptly highlighted this aspect:

\footnotetext{
${ }^{5}$ Professor Gyimah-Boadi, the then Vice Chancellor of the University of Mining and Technology, Tarkwa, although not a member of a local community, was made the co-moderator of the ASRF, which was made up by the representatives of the ten communities, the government, and eminent members of the civil society. He and his colleagues were instrumental in drafting the formal agreement between NGGL and the ASRF. In an interview, he stated that, "the agreement is the most comprehensive document ever to be enjoyed by a mining community in the country, if not in the world” (speaking to SKY FM, May 11, 2007; reported in www.Ghanaweb.com)
} 
"You will agree with me that peace is priceless. Many mining companies, globally, suffer huge operational losses because of misunderstandings, conflicts, and legal battles with their communities. The communities here do not disrupt our activities and that's a good gain for us.”

The local communities also recognised that the preservation of peace in the region necessarily entailed the sharing of company profits, which could be used in social development activities. In this context, one of the Traditional Chiefs asserted:

"They have to share the profit with us because we are giving them our natural resources. When they collaborate with us, we will be at peace. They will make their profits while we also mind our business. It means we will not disturb them with demonstrations that would disrupt their operations."

Mining is a capital-intensive industry with a long project life, and mining MNEs are inexplicably linked to the social conflicts that occur in the regions in which they operate. Most conflicts between local communities and MNEs in extractive industries stem from the issues relating to ownership, usage and acquisition of land and how the companies manage the influx of immigrants into the existing communities (Kemp et al., 2011; Carstens \& Hilson, 2009; Owusu- 
Korateng, 2008). In this context, creating and maintaining cordial relationships with the local communities is critical for MNEs to function over longer periods and to recoup their capital and operational costs. The creation of the NADeF not only enabled NGGL to operationalize its CSR activities in Ghana's Brong-Ahafo region, but also provided it with a structure through which to engage with the communities in situations of potential conflict. For instance, in a major cyanide spillage that occurred at the Ahafo Mine in 2009, the water bodies were polluted, resulting in a loss of aquatic flora and fauna. The local communities used the NADeF to successfully engage with Newmont, despite the latter being subsequently fined about five million dollars by the Government of Ghana ${ }^{6}$. As a consequence, the matter was amicably addressed without community agitations. It is important to highlight here that, compared to other parts of the world, Newmont faced limited opposition to its operation in Ghana.

The creation and successful operationalization of the NADeF contributed to the development of cordial relationships between the local communities and the company. In a sense, it provided a platform not only to share profits, but also to work together on matters central to the needs of the local stakeholders. In the structure and functioning of the NADeF, NGGL is viewed as a key sponsor of the community development activities decided upon by the members of the

\footnotetext{
${ }^{6}$ The company initially denied the charges that it had wilfully caused the cyanide spill, but the Government of Ghana upheld the accusation in 2010. (http://www.minesandcommunities.org/article.php?a=9597; accessed on 22.05.2017)
} 
SDCs. This bottom up approach to resource community development initiatives provides the company with a platform through which it can act as a 'partner in development'. According to the Director of NGGL in charge of sustainability:

"First, we want to build a solid brand for our company. We want our communities to see us as a partner in development and not just a profit-making venture.”

Clearly, being seen as a partner in development is at the core of the company's attempts to create a positive corporate image and identity, which is also critical in attracting and retaining new skilled employees to the organisation (Cable \& Turban, 2003; Turkey 2009). One of the stated objectives of the local content agreement on employment between NGGL and the mining communities was that NGGL would create job opportunities for local members. Respondents in our survey also attributed NGGL's motivation for CSR in their communities to its need to attract and retain competent and skill labour.

\subsection{Localization of CSR and the legitimisation of NGGL}

NGGL has clearly embraced a localized approach to the implementation of CSR initiatives in Ghana's Brong-Ahafo region. Consequently, we note that the company enjoys a positive image amongst the members of the local communities, who acknowledge that their relationship with 
NGGL is one of 'partners in development'-an identity that NGGL has attempted to foster in its host environment. The comments from a Youth Leader capture this view:

"NGGL sees the communities as development partners. They want to share their profit with us. I know they pay huge taxes and royalties and that local and central governments were supposed to initiate these projects. These are voluntary services they are rendering to the communities.”

A similar view was also expressed by one of the Traditional Leaders:

"I think they want to impress the public as a company that cares for the community. I belief they have succeeded in achieving this as many people come from all the corners of Ghana to look for jobs here. It appears they enjoy favourable reputation among the local people because their workers are highly respected by our people”.

The creation of a host friendly identity inevitably entails the acceptance of the company as being community friendly by the local inhabitants. These positive assertions about NGGL demonstrate how, in Ghana, the subsidiary has been accepted within the local communities. Apart from sharing profits and investing in infrastructure, housing, and schooling, and providing training and scholarships to school going children, NGGL also maintains its identity (and in the process, reinforces it) as being part and parcel of the local communities. This is exhibited in the comments made by another management employee: 
"Our office is opened to the public. We receive letters and, sometimes, petitions from interest groups. We have Information Centres in all the Communities, where members can lodge complaints and receive answers to their questions. Most of the staff manning these Centres are locals trained by the company. We act promptly to all requests because we aim at building a relationship of trust”,

Responding quickly to concerns and complaints helps in the building of cordial relationships between NGGL and the local communities. NGGL was extremely careful to adhere to the region's culture and traditions and did not alter the social structure. Its interaction with the Traditional Leaders highlights that the latter do not view their role to have been diminished after the commencement of mining operations by the company. In fact, there is greater recognition that, through NADeF, NGGL has effectively accommodated members of different stakeholder groups.

\section{Conclusion}

The purpose of this paper was to explore how MNEs use CSR as a mechanism to address issues relating to the liability of foreignness. The extant literature on MNEs and internationalisation sensitised us to the various socio-economic and political challenges faced by companies when they internationalise into culturally and institutionally unfamiliar territory. Although burgeoning research on CSR emphasised the significance of a fruitful relationship between the company and 
the society in which it is embedded (Matten \& Moon, 2008), there is little evidence pertaining to how companies actually implement their CSR strategies. In our paper, we highlight how NGGL, a Ghanaian subsidiary of Newmont Inc., a US based mining company, works closely with the NADeF to facilitate the implementation of community development initiatives. The NADeF is a unique foundation that was created in 2008 as a result of a community development agreement between NGGL and the ASRF, in which all the ten affected communities are represented.

We observe that the NADeF plays a dual role in the sense that it represents the voices of the local communities and thus helps facilitate the interaction between them and the company. In this respect, it acts as platform for conflict resolution and, in the process, helps in mitigating potential stakeholder related risks (Davis \& Frank, 2014). The NADeF also facilitates the creation of a friendly identity for Newmont Inc. in Ghana. The financial contributions made by the company in undertaking various community development initiatives are well acknowledged by the local people, which helps in enhancing corporate reputation. In that sense, the NADeF also contributes to entrench Newmont's presence in the communities (Munjal \& Pereira, 2015), which underpins the view of the parent company that its operation in Ghana presents significantly little social and political risk.

Our research suggests that foundations underpinned by community development agreements (World Bank, 2012), such as the NADeF, could potentially play a direct role in 
facilitating the localization of MNEs in host countries. Community development agreements have emerged over the last few years, particularly in the extractive sector, as an approach to ensure the sustainable development of the affected communities. These agreements in essence, provide the MNEs with a 'social licence to operate' based on the continued support of the local communities (Mayers, 2015). In this paper, we find support for this assertion.

One of the major reasons to which the failure of CSR is attributed is that it is conceptualised as a voluntary activity (Brammer et al., 2012). Although most MNEs in extractive industries have CSR strategies, they often struggle to implement them in host countries, particularly if the latter are geographically, institutionally, and politically 'remote' (Munjal \& Tripathy, 2016). In this context, we find that the NADeF has emerged as a platform for NGGL to fulfil its CSR commitments and, in the process, create a host friendly identity and enhance its corporate reputation. 


\section{$\underline{\text { References }}$}

Akabzaa, T. (2009) Ghana section of "Breaking the curse” report, Accra: Third World Network, Africa Publication.

AngloGold Ashanti, (2016). Sustainability development report, available at:

http://www.anglogoldashanti.com/en/Media/Reports/Sustainability\%20Reports/AGA-SD-

2016.pdf (assessed on 05.05.2017)

Appiah-Adu, K., \& Bawumia, M. (2016). Key determinants of national development:

Historical perspectives and implications for developing economies. Routledge.

Arendt, S., \& Brettel, M. (2010). Understanding the influence of corporate social rsponsibility on corporate identity, image, and company performance. Management Decision 48(10): 1469-1492.

Augustine, M. (2016). The role of traditional leaders in post-independence countries Botswana, Ghana and Zimbabwe, available at: http://hsf.org.za/resource-centre/hsf-briefs/therole-of-traditional-leaders-in-post-independence-countries-botswana-ghana-and-zimbabwe 
Ayee, J., Soreide, T., Shukla, G. P., \& Le, T. M. (2011). Political economy of the mining sector in Ghana.

Bachmann, S. D., \& Pereira, V. (2014). Corporate human rights responsibility and multinationality in emerging markets-a legal perspective for corporate governance and responsibility. International Journal of Business Governance and Ethics, 9(1).

Balmer, J. M. T., Fukukawa, K., \& Gray, E. (2007). The nature and management of ethical corporate identity: a commentary on corporate identity, corporate social responsibility and ethics. Journal of Business Ethics, 76(1): 7-15.

Banerjee, S. B. (2001). Corporate Citizenship and Indigenous Stakeholders: Exploring a New Dynamic of Organizational-Stakeholder Relationships. Journal of Corporate Citizenship, 1(1): 39-55. 
Bank of Ghana, (2017). Summary of Economic and Financial Data. Bank of Ghana Publication.

Bawole, J. N. (2013). Public hearing or 'hearing public'? An evaluation of the participation of local stakeholders in environmental impact assessment of Ghana’s Jubilee Oil Fields.

Environmental Management: 52(2), 385-397.

BBC, (2011). Protests in Peru halt Newmont gold mine project. Available at:

http://www.bbc.co.uk/news/world-latin-america-15956429 (accessed on 30.11.2016)

Beddewela, E., \& Fairbrass, J. (2016). Seeking legitimacy through CSR: Institutional Pressures and Corporate Responses of Multinationals in Sri Lanka. Journal of Business Ethics, 136(3): 503-522.

Blowfield, M., \& Frynas, J. G. (2005). Setting New Agendas: Critical Perspectives on Corporate Social Responsibility in the Developing World. International Affairs 81(3): 499-513.

Boateng, P. K. (2017). Land Access, Agricultural Land Use Changes and Narratives about Land Degradation in the Savannahs of Northeast Ghana during the Pre-Colonial and Colonial Periods. Social Sciences: 6(1), 35. 
Brammer, S., Jackson, G., \& Mattern, D. 2012. Corporate Social Responsibility and institutional theory: new perspectives on private governance. Socio-Economic Review, 10 (1): 3-28.

Cable, D. M., \& Turban, D. B. (2003). The value of organizational reputation in the recruitment context: A brand-equity perspective. Journal of Applied Social Psychology: 33(11), 2244-2266.

Campbell, B. (2012). Corporate Social Responsibility and development in Africa: Redefining the roles and responsibilities of public and private actors in the mining sector. Resources Policy: 37(2), 138-143.

Cooper and Schindler (2006) Business Research Methods. McGraw-Hill.

Cuervo-Cazurra, A. and Genc, M., (2008). Transforming disadvantages into advantages: developing-country MNEs in the least developed countries. Journal of International Business Studies, 39(6): 957-979.

Davis, R., \& Franks, D. M. (2014). Costs of Company-Community Conflict in the Extractive Sector. Cambridge, MA: Harvard Kennedy School. 
Dayee, D. Y., (2016). Kenyasi youth resist Newmont underground mining. Daily Guide.

Available at: http://dailyguideafrica.com/kenyasi-youth-resist-newmont-underground-mining/

DiMaggio, Paul J. and Walter W. Powell. 1983. “The Iron Cage Revisited: Institutional Isomorphism and Collective Rationality in Organizational Fields.” American Sociological Review 48:147-60.

Dunphy, D. (2003) Corporate Sustainability: Challenge to Managerial Orthodoxies', Journal of the Australian and New Zealand Academy of Management, 9(1), 2-11.

Epstein, L. and King, G. (2002). The Rules of Inference, University of Chicago Law Review 69: 191-209.

Forstater, Maya, Simon Zadek, Yang Guang, Kelly Yu, Chen Xiao Hong, and Mark George (2010), Corporate Responsibility in African Development: Insights from an Emerging Dialogue, Corporate Social Responsibility Initiative, Working Paper 60.

Garberg, N. A., \& Fombrun, C. (2006). Corporate citizenship: Creating intangible assets across institutional environment. Academy of Management Review, 31: 329-346. 
Garvin, T., McGee, T. K., Smoyer-Tomic, K. E., \& Aubynn, E. A. (2009). Community company relations in gold mining in Ghana. Journal of Environmental Management, 90(1): 571-586.

Gaur A, Delios A, Singh K. (2007). Institutional environments, staffing strategies, and subsidiary performance. Journal of Management 33(4): 611-636.

Ghanaweb, (2006). Angry youth clash with mining company Available at: http://www.ghanaweb.com/GhanaHomePage/regional/artikel.php?ID=105493

GhanaWeb, (2007) ASRF to sign agreement with Newmont Gold, available at: http://www.ghanaweb.com/GhanaHomePage/business/ASRF-to-sign-agreement-withNewmont-Gold-123889 (accessed on 15.05.2017)

Gold Fields, (2014). Integrated Annual Report for the year ended 31 December 2014, available at: https://www.goldfields.co.za/pdf/investors/integrated-annual-reports/2014/iar2014.pdf (accessed on 15.05.2017)

Government of Ghana, (1980). Report of the Committee for Increased Gold Output in Ghana. United Nations, New York. 
Halland, H., Lokanc, M., \& Nair, A. (2015). The Extractive Industries Sector: Essentials for Economists, Public Finance Professionals, and Policy Makers. World Bank Publications.

Hillenbrand, C., \& Money, K. (2007). Corporate Responsibility and Corporate Reputation: Two Separate Concepts or Two Sides of the Same Coin? Corporate Reputation Review 10(4):261-277, 10(4): 261-277.

Hilson, G. (2006). Championing the Rhetoric? Corporate Social Responsibility’ in Ghana's Mining Sector. Greener Management International, 53: 43-56.

Hilson, G. (2012) Corporate Social Responsibility in the extractive industry: Experiences from developing countries, Research Policy, 37(2), 131-137.

Hilson, G., \& Maconachie, G. (2009). "Good Governance" and the extractive industry in subsaharan Africa. Mineral Processing and Extractive Metallurgy Review, 30(1): 52-100.

Hoenen, A. K., \& Kostova, T. (2015). Utilizing the broader agency perspective for studying headquarters-subsidiary relations in multinational companies. Journal of International Business Studies, 46(1), 104-113. 
Husted, B. W., \& Allen, D. B. (2006). Corporate social responsibility in the multinational enterprise: strategic and institutional approaches Journal of International Business Studies, 37(6): 838-849.

Hymer, S. (1960/1976). The international operations of national companies: A study of direct foreign investment. Cambridge, MA: MIT Press.

IMF (2012) Regional economic outlook. Sub-Saharan Africa. Maintaining Growth in an Uncertain World, World Economic and Financial Surveys, Washington, D.C.

Jenkins, H. (2009) A Business Opportunity Model of Corporate Social Responsibility for Small-and Medium-Sized Enterprises, Business Ethics: A European Review, 18(1), 21- 36.

Jonhston, (2006). Attack on indondesia mining camp. Available at:

http://news.bbc.co.uk/1/hi/world/asia-pacific/4823842.stm (accessed on 15.05.2017).

Kindleberger C.P. (1969) American Business Abroad, The International Executive, 11, 1112.

Kostova, T., Marano, V., \& Tallman, S. (2016). Headquarters-subsidiary relationships in MNCs: Fifty years of evolving research. Journal of World Business, 51(1), 176-184. 
Kostova, T., Nell, P. C., \& Hoenen, A. K. (2016). Understanding Agency Problems in Headquarters-Subsidiary Relationships in Multinational Corporations: A Contextualized Model. Journal of Management, 0149206316648383.

Kostova, T., \& Roth, K. (2002). Adoption of an organizational practice by subsidiaries of multinational corporations: Institutional and relational effects. Academy of Management Journal, 45(1), 215-233.

Logsdon, J. M., \& Wood, D. J. (2005). Global Business Citizenship and Voluntary Codes of Ethical Conduct. Journal of Business Ethics, 59(1): 55-67.

Marano, V., \& Kostova, T. (2016). Unpacking the institutional complexity in adoption of CSR practices in multinational enterprises. Journal of Management Studies, 53(1), 28-54.

Mares, R. (2012). Corporate Responsibility and Compliance with the Law: A Case Study of Land, Dispossession, and Aftermath at Newmont's Ahafo Project in Ghana1. Business and Society Review: 117(2), 233-280.

Matten, D., \& Moon, J. (2008). "Implicit" and "Explicit" CSR: A Conceptual Framework for a Comparative Understanding of Corporate Social Responsibility. Academy of Management Review, 33(2): 404-424. 
Mayes, R. (2015). A social licence to operate: corporate social responsibility, local communities and the constitution of global production networks. Global Networks, 15 (1): $109-128$

Ministry of Lands and Natural Resources, 2012. Ghana investment plan for the forest investment program. Available (online) at: http://www.fcghana.org/assets/file/Programmes/Forest_Investment_Plan_fip/Ghana\%20Draft \%20FIP\%203-5\%20_31_august2012.pdf

Moeller, M., Harvey, M., Griffith, D., \& Richey, G. (2013). The impact of country-of-origin on the acceptance of foreign subsidiaries in host countries: An examination of the 'liabilityof-foreignness’. International Business Review, 22(1): 89-99.

Munjal, S., \& Tripathy, R. 2016. Corporate social responsibility under regulatory framework: A case study of Dedicated Freight Corridor Corporation of India, Working Paper. Leeds: University of Leeds.

Nachum, L. (2003). Liability of foreignness in global competition? Financial service affiliates in the city of London. Strategic Management Journal, 24: 1187-1208.

NADeF, 2009. Annual Report 2009 
NADeF 2015. Annual Report 2015.

Newmont, (2017a). Company at a glance, available at: http://www.newmont.com/aboutus/default.aspx (accessed on 15.05.2017)

Newmont, (2017b). About us, http://www.newmont.com/about-us/

Newmont, (2017c). Newmont Africa Region Fact Sheet, available at:

http://s1.q4cdn.com/259923520/files/doc_downloads/fact_sheets/africa/Newmont-Africa-

Factsheet.pdf (accessed on 15.05.2017)

Owusu-Ansah, D., Adu-Gyamfi, S., Brenya, E., Sarpong, Y. A., \& Damtar, D. (2015).

Corporate Social Responsibility of Mining Companies in Ghana: The case of Newmont Ghana Gold Limited at Ahafo. Journal of Social and Development Sciences, 6(4), 52.

Pereira, V. \& Malik, A. (2015). Investigating Cultural Aspects in Indian Organizations Empirical Evidence. Cham: Springer International Publishing Switzerland.

Pereira, V., Munjal, S. \& Nandakumar, M. K. (2016). Reverse dependency: A longitudinal case study investigation into headquarter- subsidiary relationship in the context of an emerging economy, International Studies of Management and Organization, 46(1), 50-62. 
Perlez, J., (2005). Cause of Mystery Ills Splits Indonesian Fishing Village. New York Times, June. Available at: http://www.nytimes.com/2005/03/27/world/asia/cause-of-mystery-illssplits-indonesian-fishing-village.html? (accessed on 12.05.2017)

Stahl, G. K., Tung, R. L., Kostova, T., \& Zellmer-Bruhn, M. (2016). Widening the lens: Rethinking distance, diversity, and foreignness in international business research through positive organizational scholarship. Journal of International Business Studies, 47 (6), 621630.

Robertson, R. (1994). Globalisation or Glocalisation? Journal of International Communication 1(1), 33-52.

Stern, R., (2016). All that glitters is not gold: Indigenous communities in Peru protest mining. Available at: http://www.dw.com/en/all-that-glitters-is-not-gold-indigenous-communities-inperu-protest-mining/a-19328199 (accessed on 12.05.2017)

Torugsa, N. A., O’Donohue, W., \& Hecker, R. (2012). Capabilities, proactive CSR and financial performance in SMEs: empirical evidence from an Australian manufacturing industry sector. Journal of Business Ethics, 109(4): 483-500.

Turker, D. (2009). How corporate social responsibility influences organizational commitment. Journal of Business Ethics: 89(2), 189-204. 
UNCTAD, (2015). World Investment Report 2015. United Nations.

US Geological Survey, (2016). Mineral Commodity Summaries. United States Geological Survey Publication.

Visser, Wayne, Dirk Matten, Manfred Pohl, Nick Tolhurst, Katja Böhmer, Aron

Ghebremariam, Judith Hennigfeld, and Sandra S. Huble. (2007). The A to Z of corporate social responsibility: a complete reference guide to concepts, codes and organisations.

Chichester, England; Hoboken, NJ: John Wiley \& Sons.

Vora, D., Kostova, T., \& Roth, K. (2007). Roles of subsidiary managers in multinational corporations: The effect of dual organizational identification. Management International Review, 47(4), 595-620.

Welford and Dixon, (2010) Corporate Social Responsibility Survey of Hang Seng Index Constituent Companies, available at: http://www.csr-asia.com/upload/OHK_CSR_survey.pdf 
Welker, M. (2009). "Corporate Security Begins in the Community": Mining, the Corporate Social Responsibility Industry, and Environmental Advocacy in Indonesia. Cultural Anthropology: 24(1), 142-179.

World Bank (2012). Mining community development agreement: Source Book.

Zaheer, S. (1995). Overcoming the liability of foreignness. Academy of Management Journal, 38(2), 341-363. 
FIGURES

Figure 1 Factors Motivating CSR Strategies of NGGL

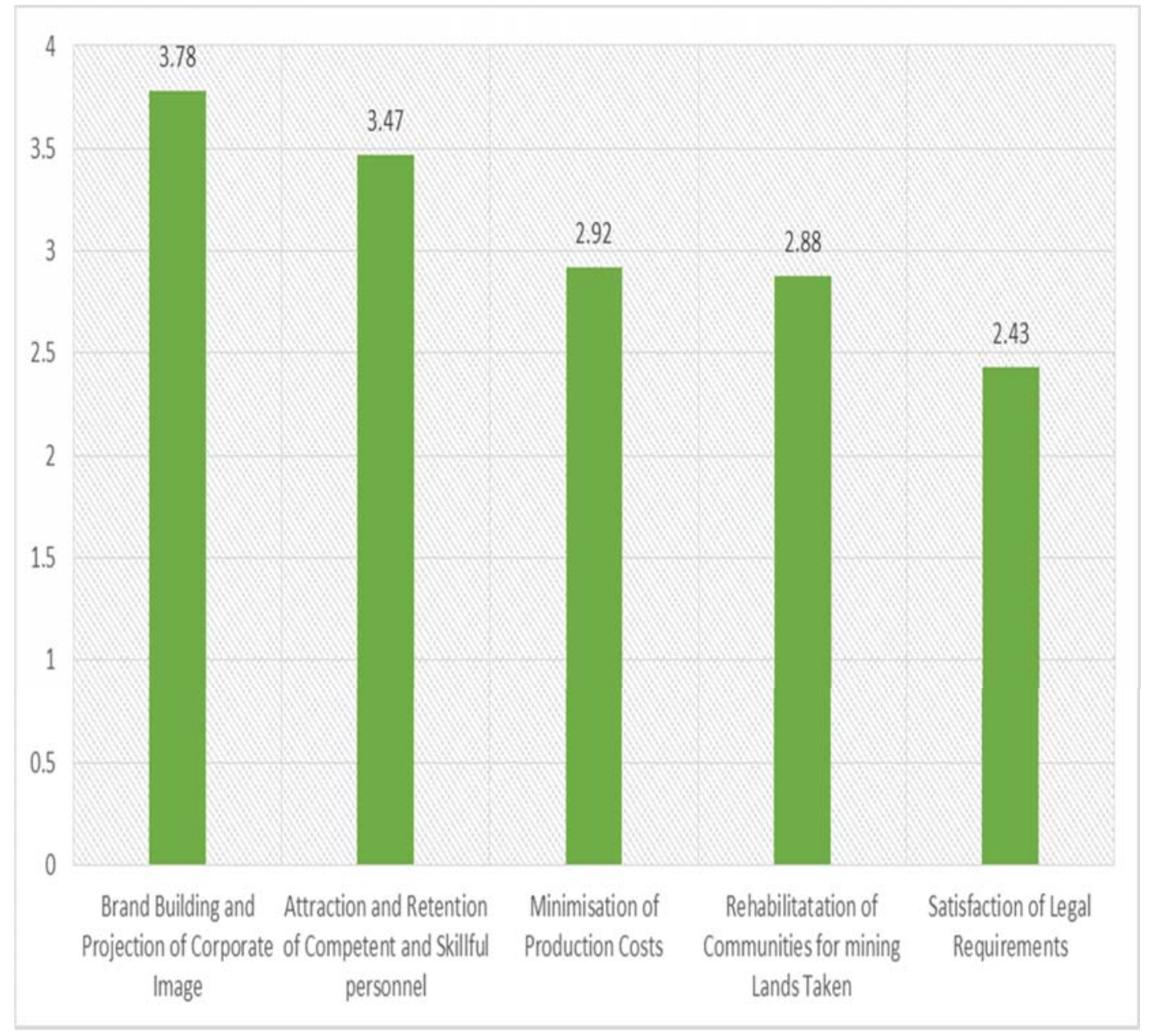


Figure 2: Developmental projects sponsored by NADeF 2008-2015 (NADeF Annual Report, 2015)

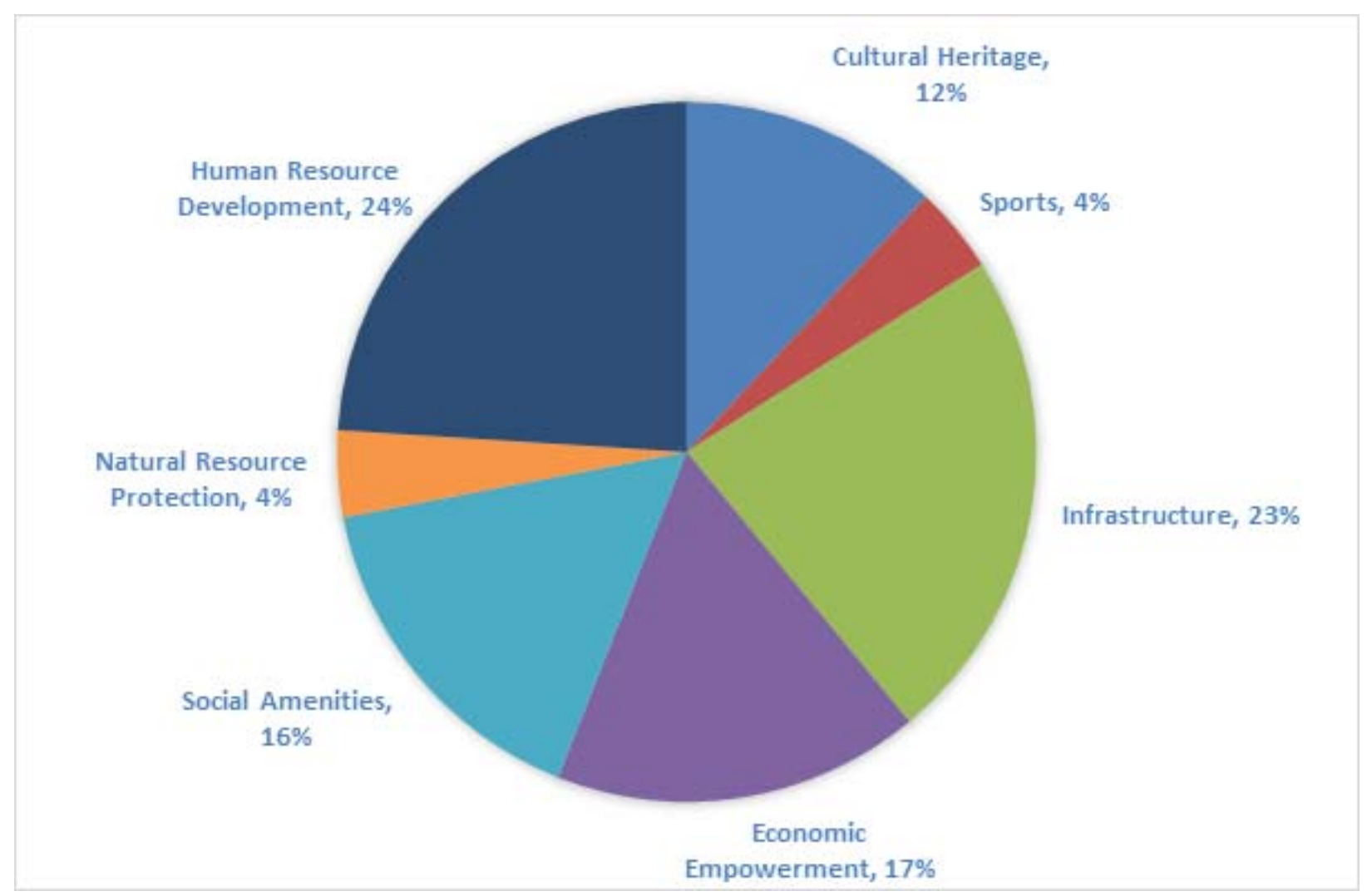


Figure 3: NADeF operational structure

\section{The Ahafo Social Responsibility Forum}

The Forum is the highest decision-making body for the NADeF, represented by traditional chiefs, civil society groups and the local people affected by the Ahafo Mine Community.

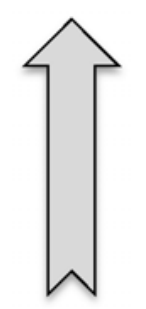

\section{Newmont Ahafo Development Foundation}

NADeF manages and invests the CSR funds through a Secretariat headed by an Executive Secretary. The Secretariat is the link between the SDC and the NADeF Board of Trustees, assessing and reviewing project needs identified by the communities.

\section{$<$}

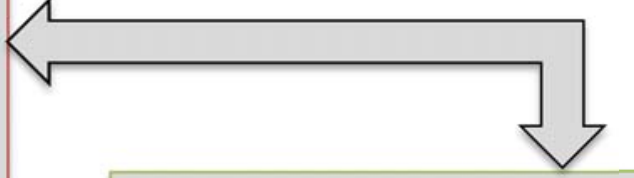

\section{Local Government}

The two Local Councils are the agents of development in the local communities. Elected Members of the Councils serve on their respective SDCs, providing technical support and ensuring that developmental projects initiated by the communities are in line with the rouncil's nlans

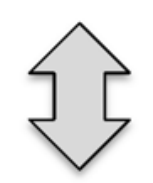

\section{Sustainable Development Committees}

The SDCs are local-level groups that consult communities to initiate/plan projects to be supported with the CSR Fund. The committees also receive complaints from people affected by mining activities and forward same to NADeF for resolution. 


\section{TABLES}

Table 1 Summary of sampled population
Gender
Rate of
Percentage
Employees
Community

Occurrence

(\%)

Members

\begin{tabular}{|l|r|r|r|r|}
\hline Male & 68 & 82.9 & 16 & 42 \\
\hline Female & 14 & 17.1 & 6 & 18 \\
\hline Total & 82 & 100 & 22 & 60 \\
\hline
\end{tabular}

Table 2 Details of Interviewees

\begin{tabular}{|l|l|l|l|}
\hline Interviewee No. & Sex & Office & Outfit \\
\hline Interviewee 1 & Male & Sustainability & NGGL \\
\hline Interviewee 2 & Male & Sustainability & NGGL \\
\hline Interviewee 3 & Male & Health and Safety & NGGL \\
\hline Interviewee 4 & Female & HRM & NGGL \\
\hline Interviewee 5 & Male & Administration & NADeF \\
\hline Interviewee 6 & Male & Trustee & NADeF \\
\hline Interviewee 7 & Male & Traditional Ruler & Community \\
\hline Interviewee 8 & Male & Traditional Ruler & Community \\
\hline Interviewee 9 & Male & Opinion Leader & Community \\
\hline Interviewee 10 & Female & Opinion Leader & Community \\
\hline Interviewee 11 & Male & Opinion Leader & Community \\
\hline Interviewee 12 & Male & Assembly Member & Local Council \\
\hline Interviewee 13 & Female & Assembly Member & Local Council \\
\hline Interviewee 14 & Female & $\begin{array}{l}\text { Unit Committee } \\
\text { Member }\end{array}$ & Local Council \\
\hline
\end{tabular}


